\title{
Variation and genetic structure of Melipona quadrifasciata Lepeletier (Hymenoptera, Apidae) populations based on ISSR pattern
}

\author{
Marcília A. Nascimento ${ }^{1}$, Henrique Batalha-Filho ${ }^{1}$, Ana M. Waldschmidt ${ }^{2}$, Mara G. Tavares ${ }^{1}$, \\ Lucio A.O. Campos ${ }^{1}$ and Tânia M.F. Salomão ${ }^{1}$ \\ ${ }^{1}$ Departamento de Biologia Geral, Universidade Federal de Viçosa, Viçosa, MG, Brazil. \\ ${ }^{2}$ Departamento de Ciências Biológicas, Universidade Estadual do Sudoeste da Bahia, Campus de Jequie, \\ Jequie, BA, Brazil.
}

\begin{abstract}
For a study of diversity and genetic structuring in Melipona quadrifasciata, 61 colonies were collected in eight locations in the state of Minas Gerais, Brazil. By means of PCR analysis, 119 ISSR bands were obtained, 80 (68\%) being polymorphic. $\mathrm{H}_{\mathrm{e}}$ and $\mathrm{H}_{B}$ were 0.20 and 0.16 , respectively. Two large groups were obtained by the UPGMA method, one formed by individuals from Januária, Urucuia, Rio Vermelho and Caeté and the other by individuals from São João Del Rei, Barbacena, Ressaquinha and Cristiano Otoni. The $\Phi s t$ and $\theta^{B}$ values were 0.65 and 0.58 , respectively, thereby indicating high population structuring. UPGMA grouping did not reveal genetic structuring of $M$. quadrifasciata in function of the tergite stripe pattern. The significant correlation between dissimilarity values and geographic distances $(r=0.3998 ; p<0.05)$ implies possible geographic isolation. The genetic differentiation in population grouping was probably the result of an interruption in gene flow, brought about by geographic barriers between mutually close geographical locations. Our results also demonstrate the potential of ISSR markers in the study of Melipona quadrifasciata population structuring, possibly applicable to the studies of other bee species.
\end{abstract}

Key words: Hymenoptera, Melipona, genetic differentiation, ISSR markers, population structure.

Received: May 19, 2009; Accepted: December 21, 2009.

Melipona quadrifasciata Lepeletier, 1836 is a stingless bee distributed along the eastern Brazilian coast, from Rio Grande do Sul to Paraíba, extending westwards inland towards Misiones, in Argentina, and southeastern Paraguay (Moure and Kerr, 1950). Traditionally, two different subspecies are recognized, M. quadrifasciata quadrifasciata and M. quadrifasciata anthidioides. Their main difference lies in the yellow tergite stripes from the $3^{\text {rd }}$ to the $6^{\text {th }}$ segment that are continuous in $M$. $q$. quadrifasciata but discontinuous in M. q. anthidioides (Schwarz, 1932). The subspecies M. q. quadrifasciata is found in the south in the states of São Paulo, Paraná, Santa Catarina and Rio Grande do Sul (Kerr, 1951; Moure, 1975), whereas M. q. anthidioides is found from northern and northeastern São Paulo State, eastward up to Paraiba (Kerr, 1951). Populations with a tergite stripe pattern similar to $M$. q. quadrifasciata have been reported in northern Minas Gerais, Sergipe and northeastern Bahia (Batalha-Filho et al., 2009). However, the bees from northern Minas Gerais and northeastern Bahia and Sergipe, differ genetically from

Send correspondence to Tânia Maria Fernandes Salomão. Departamento de Biologia Geral, Universidade Federal de Viçosa, Avenida PH Rolfs S/N, 36570-000 Viçosa, MG, Brazil. E-mail: fernands@ufv.br.
M. q. quadrifasciata and are similar to M. q. anthidioides. Waldschmidt et al. (2000), for example, when studying these two Melipona subspecies, detected a RAPD marker in individuals from Januária (northern Minas Gerais) that was present in $M . q$. anthidioides, but absent in $M$. $q$. quadrifasciata. Similarly, Batalha-Filho et al. (2009), based on PCR-RFLP analysis of the COI gene, showed genetic similarity between $M$. q. anthidioides and $M$. quadrifasciata from northern Minas Gerais, northeastern Bahia and Sergipe, both with a tergite stripe pattern similar to that of M. q. quadrifasciata.

Through population analysis of M. quadrifasciata, the difference between the two subspecies could be emphasized (Waldschmidt et al., 2000; Souza et al., 2008), although there are still no reports of studies assessing $M$. quadrifasciata population structuring in itself. Among the techniques that can be used to ascertain population structure, PCR-ISSR has proved to be outstanding in the analysis of natural populations of many plant, fungus, insect and vertebrate species (Wolfe, 2005). Although the importance of this marker in population analysis in insects has been widely shown, studies in the particular case of bees are rare. Berezovskaya et al. (2002) detected inter-specific genetic variation in five species of the genus Bombus, thereby dem- 
onstrating that the ISSR marker could be useful in helping to elucidate problems linked to its taxonomic classification. Paplauskiené et al. (2006) detected specific ISSR markers for the subspecies Apis mellifera carnica and Apis mellifera caucasica that permitted genetic differentiation between the two.

In this study, ISSR polymorphism was assessed and used for characterizing the population structure of $M$. quadrifasciata from different localities in Minas Gerais, thereby constituting the first appraisal of populations with bees of the Meliponini tribe using the PCR-ISSR approach.

Workers from 61 Melipona quadrifasciata colonies from eight locations in the state of Minas Gerais, Brazil (Figure 1) were sampled, with one individual per colony being analyzed. Some individuals had different morphological characteristics as regards the abdominal tergite stripe pattern. The locations, number of colonies per location and tergite stripe pattern of the individuals analyzed, can be seen in Table 1 .

Genomic DNA was extracted as recommended by Waldschmidt et al. (1997). In a preliminary analysis, 93 ISSR primers (UBC Kit) were tested, whereupon 20 were selected based on band reproducibility and definition. The effects of primer concentration $(0.05 ; 0.10$ and $0.15 \mu \mathrm{M})$, DNA template (10 and $50 \mathrm{ng}$ ) and annealing temperature $\left(48-60{ }^{\circ} \mathrm{C}\right)$, were tested. After optimizing amplification re-

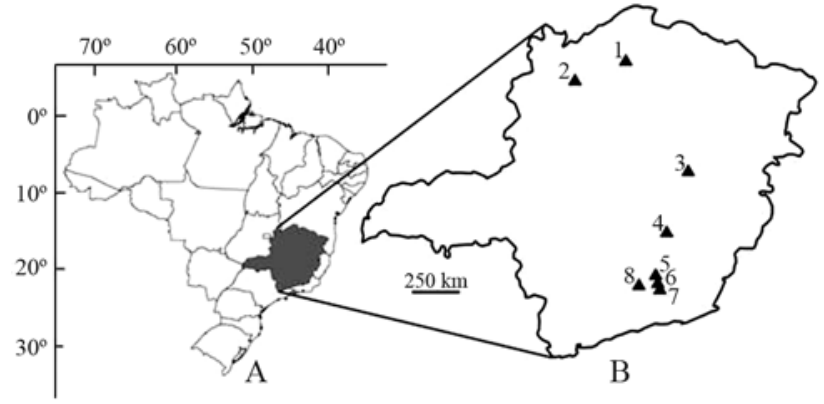

Figure 1 - Map of Brazil (A) and the state of Minas Gerais (B) indicating sampled locations of the Melipona quadrifasciata. 1- Urucuia (UR), 2Januária (JA), 3- Rio Vermelho (RV), 4- Caeté (CA), 5- Cristiano Otoni (CO), 6-Barbacena, 7-Ressaquinha (RE), 8- São João Del Rei (SJ).

Table 1 - Sampled localities, sample size (n) and pattern of abdominal stripes of Melipona quadrifasciata from Minas Gerais State, Brazil.

\begin{tabular}{lcl}
\hline Code /Location & Number of specimens (n) & Tergite stripe pattern \\
\hline JA-Januária & 10 & Continuous \\
UR-Urucuia & 10 & Continuous \\
BA-Barbacena & 4 & discontinuous \\
RE-Ressaquinha & 4 & discontinuous \\
RV-Rio Vermelho & 10 & discontinuous \\
CO-Cristiano Otoni & 7 & discontinuous \\
SJ-São João Del Rei & 6 & discontinuous \\
CA-Caeté & 10 & discontinuous \\
\hline
\end{tabular}

actions, nine primers denominated UBC $807\left(54^{\circ} \mathrm{C}\right)$, UBC $808\left(54{ }^{\circ} \mathrm{C}\right), \mathrm{UBC} 834\left(48^{\circ} \mathrm{C}\right), \mathrm{UBC} 836\left(54^{\circ} \mathrm{C}\right), \mathrm{UBC} 840$ $\left(50{ }^{\circ} \mathrm{C}\right), \mathrm{UBC} 842\left(56^{\circ} \mathrm{C}\right), \mathrm{UBC} 848\left(56^{\circ} \mathrm{C}\right)$, UBC 856 $\left(48^{\circ} \mathrm{C}\right)$ and $\mathrm{UBC} 857\left(50^{\circ} \mathrm{C}\right)$ were used in the genetic analyses.

The reaction mixture $(25 \mu \mathrm{L})$ contained $10 \mathrm{ng}$ of DNA, $2.0 \mu \mathrm{L}$ of dNTPs at $100 \mu \mathrm{M}, 2.5 \mu \mathrm{L}$ of a $10 \mathrm{X}$ buffer, 0.5 U Taq DNA polymerase (Prodimol) and 50 pmoles primers. Amplification conditions included initial denaturation at $94{ }^{\circ} \mathrm{C}$ for $3 \mathrm{~min}$, followed by 40 cycles of $1 \mathrm{~min}$ at $92{ }^{\circ} \mathrm{C}, 2 \mathrm{~min}$ at primer annealing temperature, $2 \mathrm{~min}$ at $72{ }^{\circ} \mathrm{C}$, and a final step of $7 \mathrm{~min}$ at $72^{\circ} \mathrm{C}$. The reactions were accompanied by a negative control containing all the components, with the exception of genomic DNA. The PCR products were separated by electrophoresis in $1.5 \%(\mathrm{p} / \mathrm{v})$ agarose gel, and visualized by staining with ethidium bromide $(0.2 \mu \mathrm{g} / \mathrm{mL})$ and photodocumented using the AlphaDigiDoc system.

Amplification products were codified as binary traits according to band presence (1) and absence (0). The percentage of polymorphic loci and genetic diversity $(\mathrm{He})$ were estimated using the TFPGA program 1.3 version (Miller, 1997). Grouping was analyzed by a genetic dissimilarity matrix between the colonies analyzed, based on the Dice index (Dice, 1945), and by the UPGMA method with the aid of the NTSYS program (Rohlf, 2005). The analysis of molecular variance (AMOVA) for studying population structuring was carried out according to Excoffier et al. (1992), using the Arlequim 3.01 program (Excoffier et al., 2006). The significance of structuring was tested with 1000 permutations, where $\mathrm{P}$ showed the probability of observing a random value equal to or greater than the value observed. Non-differentiation among the locations analyzed was ascertained by exact testing. Genetic diversity and degree of structuring were also analyzed by means of the HICKORY program (Holsinger and Lewis, 2005), using the free $f$ model. In this analysis, the $\mathrm{H}_{\mathrm{B}}$ value was analogous to $\mathrm{H}_{\mathrm{e}}$, and the $\theta^{\mathrm{B}}$ value to $\Phi$ st of the AMOVA. The spatial distribution pattern based on genetic distance was assessed through the Mantel test using the GENES program v. 2007.0.0 (Cruz, 2007).

Amplifications with clear and reproducible band patterns were available from only nine of the 93 initially assessed ISSR primers (UBC Kit). PCR reactions involving these nine primers resulted in 119 DNA bands, of which 80 were polymorphic $(68 \%)$. The number of bands per primer ranged from 8 to 16 , with a mean of 13 bands per primer, the reactions with UBC-807 and UBC-834 primers presenting the highest number of bands (16). The value of $67 \%$ ISSR polymorphism detected in Melipona quadrifasciata was considered high and fairly close to that estimated for the subspecies Apis. mellifera. carnica and Apis. mellifera. Caucásica (66.7\%), also when applying ISSR polymorphism (Paplauskiene et al., 2006). 
Genetic diversity $\left(\mathrm{H}_{\mathrm{e}}\right)$, assuming Hardy-Weinberg equilibrium was 0.20 , and the $\mathrm{H}_{\mathrm{B}}$ estimate based on Bayesian analysis, that does not assume the Hardy-Weinberg equilibrium, was 0.16 . Low diversity values have also been reported in studies on other Hymenoptera and were justified by the haplodiploidy system associated to the effective size of the population, social behavior and environmental variation (Graur, 1985).

The grouping analysis (UPGMA) at the level of 0.75 genetic similarities separated the specimens into two large groups. The first group supported by bootstrap value of 99\% comprised the samples from Januária, Urucuia, Rio Vermelho and Caeté, whereas the second supported by a bootstrap value of $55 \%$ consisted of those from São João Del Rei, Barbacena, Ressaquinha and Cristiano Otoni (Figure 2). The significant correlation between dissimilarity values and geographic distances $(r=0.3998 ; \mathrm{p}<0.05)$ determined by the Mantel test, implied possible isolation by geographic distance and the structuring into two large groups might be reflecting this.

Genetic differentiation within populations was probably the outcome of interrupted gene flow, caused by geographic barriers between otherwise geographically close neighbors. This population isolation, as reflected in local genetic structuring, probably arose from the rough geographical topography of Minas Gerais. This hypothesis is supported in studies undertaken by Batalha-Filho et al. (2009), who reported that M.q. anthidioides is associated with higher altitudes throughout mountain ranges in Minas Gerais, Espirito Santo and Bahia and absent in the lowlands in northern Espirito Santo, southern Bahia and areas in the upper São Francisco river.

UPGMA grouping revealed no genetic structuring associated with the tergite stripe pattern in these bees. The first group supported by a high bootstrap value (bootstrap $=99 \%$ ) included M. quadrifasciata from Januária and Urucuia with continuous tergite stripe pattern and individuals from Rio Vermelho and Caeté in which this pattern is discontinuous. Retained ancestral polymorphism could possibly cause incongruence between ISSR profiles and tergite stripe patterns. Similar results were reported by



Figure 2 - Diagram of genetic similarity obtained by the UPGMA method using the DICE index. Numbers alongside branches refer to bootstrap values (1000 replicates). The column on the right indicates the code of sampled localities.

Batalha-Filho et al. (2009) through PCR-RFLP of the COI gene, and in phylogeographic studies that analyzed sequences of the Cyt b gene of these bees (Batalha-Filho et al., 2010). Likewise, Souza et al. (2008) investigated patterns of the Cyt $b$ gene, also with PCR-RFLP, whereby they demonstrated a relationship between both RFLP and tergite stripe patterns.

The analysis of molecular variance (AMOVA) showed that the percentage of variation among locations $(58.81 \%)$ was higher than that within locations $(41.19 \%)$. The $\Phi$ st ( 0.59$)$ showed a high population structuring. The values of the $\Phi$ st matrix pair by pair between locations confirmed the high differentiation of M. quadrifasciata in the state of Minas Gerais (Table 2). Analysis, by applying the

Table 2 - Matrix of $\Phi$ st values for each pairwise combination among specimes from eight localities based on 80 ISSR loci.

\begin{tabular}{|c|c|c|c|c|c|c|c|c|}
\hline Location & JÁ & UR & $\mathrm{CA}$ & RV & SJ & BA & $\mathrm{RE}$ & $\mathrm{CO}$ \\
\hline JÁ & 0.00000 & & & & & & & \\
\hline UR & 0.49610 & 0.00000 & & & & & & \\
\hline CA & 0.45649 & 0.50308 & 0.00000 & & & & & \\
\hline $\mathrm{RV}$ & 0.49604 & 0.49956 & 0.38514 & 0.00000 & & & & \\
\hline SJ & 0.68202 & 0.66954 & 0.62551 & 0.57285 & 0.00000 & & & \\
\hline BA & 0.65050 & 0.67795 & 0.66141 & 0.63524 & 0.53391 & 0.00000 & & \\
\hline $\mathrm{RE}$ & 0.68293 & 0.69245 & 0.63766 & 0.60428 & 0.41472 & 0.53064 & 0.00000 & \\
\hline $\mathrm{CO}$ & 0.67896 & 0.70995 & 0.65768 & 0.63403 & 0.53504 & 0.59365 & 0.37278 & 0.00000 \\
\hline
\end{tabular}


Bayesian method, indicated values in line with AMOVA, where the $\theta^{\mathrm{B}}$ values confirmed the high genetic structuring suggested by the $\Phi$ st.

AMOVA (Фst $=0.59)$ and Bayesian analysis $\left(\theta^{\mathrm{B}}=0.58\right)$ also showed that the two groups were highly structured. Evidence that M. quadrifasciata is found structured in the localities assessed in the present study was also reported by Batalha-Filho et al. (2010) based on phylogeographical studies.

In short, it was shown that M. quadrifasciata genetic structuring, while not expressed in the tergite stripe pattern, could be related to geographic isolation. Furthermore, the potential of the ISSR marker in studies of population structuring in M. quadrifasciata was also demonstrated, this possibly constituting a useful aid in the studies of other bee species.

\section{Acknowledgments}

The authors wish to thank the Secretaria de Estado de Educação do Mato Grosso (SEDUC/MT), as well as the Universidade Federal de Viçosa (UFV), Conselho Nacional de Desenvolvimento Científico Tecnológico (CNPq) and Fundação de Amparo à Pesquisa do Estado de Minas Gerais (FAPEMIG) for financial support.

\section{References}

Batalha-Filho H, Melo GAR, Waldschmidt AM, Campos LAO and Fernandes-Salomão TM (2009) Geographic distribution and spatial differentiation in the color pattern of abdominal stripes of the Neotropical stingless bee Melipona quadrifasciata (Hymenoptera, Apidae). Zoologia 26:213219.

Batalha-Filho H, Waldschmidt AM, Campos LAO, Tavares MG and Fernandes-Salomão TM (2010) Phylogeography and historical demography of the Neotropical stingless bee Melipona quadrifasciata (Hymenoptera, Apidae): Incongruence between morphology and mitochondrial DNA. Apidologie (in press).

Berezovskaya OP, Moroz OY and Sidorenko AP (2002) Intra-and interspecific diferences in ISSR-PCR characteristics of Bumble bees (Hymenoptera, Bombinae). Cytol Genet 36:25-31.

Cruz CD (2007). Programa Genes: Aplicativo Computacional em Genética e Estatística, Versão Windows. UFV, Viçosa.

Dice LR (1945) Measures of the amount of ecological association between species. Ecology 26:297-302.
Excoffier L, Smouse PE and Quattro JM (1992) Analysis of molecular variance inferred from metric distances among DNA haplotypes: Application to human mitochondrial DNA restriction data. Genetics 131:479-491.

Excoffier L, Laval G and Schneider S (2006) Arlequim 3.01. An integrated software package for population genetics data analysis. Computational and molecular population genetics lab (CMPG). Institute of Zoology, University of Berne.

Graur D (1985) Gene diversity in Hymenoptera. Evolution 39:190-199.

Holsinger KE and Lewis PO (2005) A Package for Analysis of Population Genetic Data. University of Connecticut, Storrs.

Kerr WE (1951) Estudos sobre a genética de populações de himenópteros em geral e dos apíneos sociais em particular. Tese para livre Docência. An Esc Sup Agric Luiz de Queiroz 8:219-354.

Miller MP (1997) Tools for population genetic analysis (TFPGA), version 1.3: A Windows program for analysis of allozyme and molecular population genetic data. University of Northem Arizona, Flagstaff.

Moure JS (1975) Notas sobre as espécies de Melipona descritas por Lepetelier em 1836 (Hymenoptera, Apidae). Rev Bras Biol 3:15-17.

Moure JS and Kerr WE (1950) Sugestões para a modificação da sistemática do gênero Melipona (Hymen, Apoidea). Dusenia 1:105-129.

Paplauskiené V, Ceksteryte V, Paplauskiené I, Tamasauskiene D and Racys J (2006) The use of ISSR for the assessment of genetic diversity. Biologija 3:16-20.

Rohlf FJ (2005) NTSYS - pc. Numerical taxonomy and multivariate analysis system. Exeter Software, New York.

Schwarz HF (1932) The genus Melipona. Bull Am Mus Nat Hist 63:231-460.

Souza RO, Moretto G, Arias MC and Del Lama MA (2008) Differentiation of Melipona quadrifasciata L. (Hymenoptera, Apidae, Meliponini) subspecies using cytochrome b PCRRFLP patterns. Genet Mol Biol 30:445-450.

Waldschmidt AM, Barros EG and Campos LAO (2000). A molecular marker distinguishes the subspecies Melipona quadrifasciata quadrifasciata and Melipona quadrifasciata anthidioides (Hymenoptera, Apidae, Meliponinae). Genet Mol Biol 3:609-611.

Waldschmidt AM, Salomão TMF, Barros EG and Campos LAO (1997) Extraction of genomic DNA from Melipona quadrifasciata (Hymenoptera, Apidae, Meliponinae). Braz J Genet 20:421-423.

Wolfe AD (2005) ISSR techniques for evolutionary biology. Meth Enzymol 395:134-144.

Associate Editor: Fábio de Melo Sene

License information: This is an open-access article distributed under the terms of the Creative Commons Attribution License, which permits unrestricted use, distribution, and reproduction in any medium, provided the original work is properly cited. 